Obstacles to green building project financing: an empirical study in Ghana

Kofi Agyekumª, Alex Opoku ${ }^{\mathrm{b}}$, Anthony James Oppon ${ }^{\mathrm{c}}$ and De-Graft Joe $\mathrm{Opoku}^{\mathrm{d}^{*}}$

a,c Department of Construction Technology and Management, Kwame Nkrumah University of Science and Technology, Kumasi, Ghana; ${ }^{b}$ Bartlett School of Construction \& Project Management, University College London, UK; ${ }^{d}$ Centre for Smart Modern Construction, School of Built Environment, Western Sydney University, Sydney, Australia

kagyekum.cap@knust.edu.gh, alex.opoku@ucl.ac.uk, anthonyjamesoppon@gmail.com, joedeggie2000@gmail.com

*corresponding author: joedeggie2000@gmail.com 


\title{
Obstacles to green building project financing: an empirical study in Ghana
}

\begin{abstract}
This study examines the perception of professionals in the Ghanaian construction industry regarding the obstacles to green building project financing. Following an extensive critical comparative review of literature resulting in the identification of ten potential obstacles, a cross-sectional survey was conducted among 520 construction industry professionals. Data obtained from the survey were analysed using both descriptive and inferential statistics. The findings from the study revealed that split incentives, risk related barriers, capital expenditure, lack of incentives, and initial capital cost are the key obstacles that hinder green building project financing. The findings further revealed significant differences in the views of the professionals regarding four obstacles to green building project financing. From the discussion, it was realised that for some of the identified obstacles, the differences resulted from the fact that the different professionals have different interests in green building projects, and those interests depict the kind of risks they are exposed to. The value of this paper is to help built environment professionals to understand these obstacles and find a better way of turning these challenges into opportunities for the construction industry.
\end{abstract}

Keywords: construction professionals; green building projects; project financing; Ghana; obstacles; construction industry

\subsection{Introduction}

Though the construction industry positively impacts urbanization through living and working spaces, as well as the national economy, its associated activities are reported to rapidly depress the environment (Oluwunmi et al., 2019). Currently, the building sector leads to the consumption of world energy sources and other resources like ores, wood, and the likes (Shi and Liu, 2019). The United Nations Environment Programme, UNEP, pegs the energy consumption in the building industry at $40 \%$. In addition to this, the amount of carbon dioxide emitted into the atmosphere by the construction industry is 
estimated to be enormous (Zuo and Zhao, 2014). About 171 countries around the world have now set up their environmental management systems and frameworks (through ISO 14000) to solve environmental issues that result from their greenhouse gas emissions (Tam et al., 2019). With the global population estimated to increase to about 9.8 billion by 2050 (United Nations Department of Economics and Social Affairs, UNDESA, 2017), there is no doubt that the demand for energy as well as other resources will also increase. In the view of Oluwunmi et al. (2019), the livelihood of man depends on buildings; however, the development of the buildings should be such that it has no or low adverse effect on the environment. This ideology of putting up buildings without harming the environment has now brought the twenty-first-century construction industry into the concept of green buildings.

The advantages associated with the adoption of green buildings are well reported in the literature (Zhang et al., 2018; United States Environmental Protection Agency, USEPA, 2015). Following most of these benefits, green buildings have now been considered as the biggest investment opportunity for the next decade both by financiers and investors, governments, developers, and owners across the world (International Finance Corporation, IFC, 2019). This notwithstanding, despite the increase in green building certification programs, its yearly square footage coverage is far from the total floor area of the huge building market (Zhang et al., 2019). This issue is partly due to the many restrictions on the promotion of green buildings, with the issue of finance or investment of dominance.

According to the IFC (2019), currently, the size of investments made by investors in green buildings is just a fraction of the available investment opportunity. Out of the $\$ 5$ 
trillion spent on general building construction and renovation worldwide in 2017, green building investments was estimated to be $\$ 423$ billion (IFC, 2019). For emerging markets like Sub-Saharan Africa, though there is that push for green buildings, there is the struggle to identify and implement effective measures that can encourage the adoption of large-scale green construction practices and technologies (IFC, 2019). In Ghana, for instance, such ambitions are downplayed by the lack of adequate funds to finance such projects (Ampratwum et al., 2019; Agyekum et al., 2019).

The IFC (2019) acknowledges some of these challenges associated with green building developments in Sub-Saharan Africa but posits that it is possible to realize the full investment potential of green buildings because of the presence of the resources needed to do so. To achieve this, key stakeholders like investors, developers, owners, and the government are tasked to pull their resources together to meet demands for buildings in a way that is sustainable (IFC, 2019). This solution may work in some developed countries. However, in a developing country like Ghana, how can this work if stakeholders are faced with potential obstacles? The obstacles to financing green buildings is a problem that requires a collaborative effort of all stakeholders to mitigate it. This study therefore presents the views of key professionals on potential obstacles to green building project financing in Ghana.

\subsection{Literature Review}

\subsection{Definitions of green building}

Mao et al. (2009) indicated that the development of green buildings is traced to the crisis in the energy sector that occurred around 1960, and which created the urgency for research to tackle ways of improving energy efficiency worldwide while decreasing 
environmental pollutions. In combination with the energetic environmental movement in those times, the early research experiments paved the way for the contemporary drive for green buildings, which evolved from implementing best practices to produce buildings which were energy-efficient and environmentally friendly (Zhang et al., 2019). Though there are these developments, Zhang et al. (2019) further indicated that green buildings cannot be defined easily because of the varying opinions regarding the concept. This assertion by Zhang et al. (2019) had been iterated by the World Green Building Council, WGBC, (2018) that claimed that the different characteristics (e.g. climatic conditions, history, culture, traditions, etc.) of a country shape the green building methods adopted by that country. Since green building developments are not the same across the world, the definition provided for it by a particular country most of the times represent the requirements of the building industry of that country (Zhang et al., 2019).

According to the Building and Construction Authority, BCA, (2014), green building is an energy and water-efficient building which possesses a healthy indoor environment, and which is formed from eco-friendly materials. In China, the Assessments Standard of Green Buildings defines green buildings as buildings that save resources throughout the whole building lifecycle (Ministry of Housing and Urban-Rural Development, MOHURD, 2015). However, the World Green Building Council (WGBC) defined green buildings as that which reduces negative impacts in its design, construction, and operation, and which positively impacts the eco-system (WGBC, 2018). Sustainable or green buildings can also be the practice of using processes that are environmentally responsible and resource-efficient throughout the lifecycle of a building (USEPA, 2009). The United States Green Building Council, USGBC, agreed with this definition 
and stipulated that in such buildings there is the need to think through the planning, design, and construction practices (Kriss, 2014).

The development of green buildings has now become a worldwide concept and most developed nations have implemented various certification tools to certify their buildings. This concept is also gradually being bought within the developing nations, some of which have also instituted some certification tools for their buildings. In Africa, Ghana is among the countries which are increasingly becoming aware of the benefits associated with green buildings (Agyekum et al., 2020; Ampratwum et al., 2019).

\subsection{Financing green or sustainable buildings}

In a study conducted by Lee et al. (2013), it was revealed that there has been a paradigm shift from traditional buildings to sustainable or green buildings to reduce the damage to the environment. In the view of Dania (2017), the importance of sustainable buildings has gained attention in recent years. This notwithstanding, it is a fact that a huge amount of finance is needed to allow for sustainable development to achieve climate and environmental objectives (Walter et al., 2017). Whereas there seem to be no options available, some experts have recommended the patronage of green finance to support the development of green buildings. Though quite difficult to explain, several studies have attempted to define green finance.

According to the G20 Green Finance Study Group (2016), green finance involves the financing of investments that provides environmental benefits in the broader context of environmentally sustainable development. Höhne et al. (2012) indicated that green finance is a broad term and refers to the financial investments that flow into sustainable development projects and initiatives, environmental products, and policies that can 
encourage the development of a more sustainable economy. In the view of Zadek and Flynn (2013), the term is often used interchangeably with green investment, but it is of a wider lens and includes more than investments. Zadek and Flynn (2013) further postulated that green finance includes operational costs of green investments not included in the definition of green investment.

Exporting some of these definitions in the context of green buildings, green building project financing has been defined differently by various researchers. According to Shan et al. (2017), the concept refers to raising financial capital for the development of sustainable building projects. Höhne et al. (2012) added their views and indicated that such financing involves a financial investment that is geared towards sustainable building projects. Some studies have reported on certain financial vehicles (investment tools used to finance projects) for green building project financing. Literature reports on such financial vehicles to include Government Interventions (Chakravarthi and Aravindan, 2019), Green Bonds (Salman et al., 2016), Bank loans (Cui et al., 2018), International Assistance (IFC, 2017), and Private funding (Zhan and de Jong).

\subsection{Obstacles to financing green buildings}

An extensive critical comparative review of the literature was conducted and potential obstacles to green building project financing were identified. Among the obstacles identified in the review and described below are lack of credible information database; risk-related barriers; lack of knowledge about green building benefits; inadequate financing schemes; capital expenditure; split incentives; lack of incentives; new technology; changing government policies; and initial capital cost. 


\subsubsection{Lack of credible information database}

Notwithstanding the progress made globally to advocate for sustainable construction projects to save the environment, lack of information or knowledge has been one of the significant barriers to increased investment and capital mobilization for such projects (Green Climate Fund, 2017). According to the United Nations Environmental Programme (UNEP), (2010), understanding of sustainable construction projects among various professionals is limited thereby making it difficult for such professionals to deal with the financing aspects of sustainable construction projects. This issue is more profound in the financial sector (Weber et al., 2014). Volz (2018) reinforced the fact that only a few professionals, especially in the finance sector had information or knowledge on sustainability issues that they can use to advise or inform investors on the profitability of financing sustainable construction projects. These problems may stem from the fact that such institutions do not have credible information/databases on such sustainable projects. In the view of Clark et al. (2018), lack of information and inconsistent data on investment in a sustainable construction project can lead to risky financial decisions on such projects with regards to the returns on the investment.

\subsubsection{Risk related barriers}

Green building projects are plagued with various kinds of risks. Some of the risks factors in green building projects are identified to include macro-economic risks (Zhao et al., 2016), client-related risks, safety risks (Yang et al., 2016), human resource risks (Qin et al., 2016), project team risks (Hwang et al., 2017), cost overrun risks (Zhao et al., 2016), financial risks, liability and litigation risks, performance risks, legislative risks, industry risks, market risks, and the likes (UNEP, 2010). Though all of these risks are important, some investors are particular about the liability and litigation risk since it could easily prevent them from investing in green building projects (UNEP, 2010). 
Where developers and owners require green building elements for which design firms and contractors may not be insured, liability risks could arise (UNEP, 2010). The risks associated with litigation also tend to delay efforts in addressing other barriers to green buildings (UNEP, 2010). In the view of Azizi (2010), regulatory risks could occur where a government's priorities change by maintaining regulations for sustainable projects but with the removal of incentives. In the case of performance risk, Azizi (2010) noted that many industry practitioners viewed the performance of materials, systems, and its implementation in the buildings as a risk.

\subsubsection{Lack of knowledge about green building benefits}

Studies have shown that investing in green buildings will not only benefit the buyers and consumers but also provide business opportunities for all stakeholders within the built environment (Nduka and Sotumbo, 2014). The benefits associated with green buildings are listed to include environmental (e.g. conservation of natural resources), health and community (e.g. enhancing occupants' comfort and health), financial (e.g. reduced operating costs), market (e.g. higher occupancy rate), and industrial benefits (e.g. increasing job opportunities) (Durmus-Pedini and Ashuri, 2010). Unfortunately, in most developing countries, there is a lack of information concerning the full benefits that green buildings can offer, which makes it difficult for people to want to invest in such buildings (Simpeh and Smallwood, 2015).

\subsubsection{Inadequate financing schemes}

Construction is a capital-intensive venture that requires much financing. Lack of funds to invest in sustainable building projects has been noted as one of the barriers impeding the implementation of sustainable practices in the construction industry (Ampratwum et 
al., 2019). According to Gou et al. (2013), obtaining financing from banks can be challenging for developers of sustainable construction projects, making it difficult for investors and developers to increase their investment in the area. Lack of financing mechanisms to fund sustainable projects has significantly challenged the industry from expanding the number of sustainable construction projects (Gou et al., 3013).

\subsubsection{Split incentives}

The challenge of split incentives is not only peculiar to the financial sector but it is an obstacle to any organization that seeks to invest in the green building sector (UNEP, 2010). It occurs "when the flow of investments and benefits are not properly rationed among the parties to a transaction" (UNEP, p. 20). It is also a circumstance where investments and benefits are not allocated equally among users and developers, which slows the rate of investment in a particular sector (Bird and Hernandez, 2012). The situation where the benefits that accrue from an investment do not go to the party that financed it, but rather another party enjoys the interests of the investment a split incentive is realized. According to Sourani and Sohail (2011), quite often the party responsible for capital investment is not the same party that reaps the benefits during the operational life cycle of the building. Therefore the parties are not interested in investing in such a project.

With regards to sustainable or green buildings, a split incentive is a key problem that poses a challenge to pursuing energy efficiency investments in rental buildings (UNEP, 2010). According to Economidus (2014), this situation is mostly related to cost recovery of energy efficiency upgrades due to the failure of allocating effectively financial obligations and rewards of these investments between concerned parties and 
may trigger inaction from both parties even though the investment may present positive results.

\subsubsection{Other obstacles to financing green buildings}

Discussed above are some key obstacles to financing green buildings. Other equally significant obstacles are lack of incentives, new technology, changing government policies, initial capital cost, and capital expenditure.

Lack of incentives, initial capital cost, and capital expenditure can all be classified under cost-related barriers. There is the perception that the cost of sustainable buildings is higher than that of a traditional building, and this hinders the promotion of financing such buildings (Abdin and Azizi, 2016). In a report by Marsh (2009), financial risk was ranked as the number one on the list of top five risks associated with sustainable buildings. Some of the factors that accounted for the increased risk in financing such projects include failure to secure incentives and grants as part of the project, initial capital cost (including the cost of the certification process), and increased risk of delay. Yudelson (2010) stated that it is an undeniable fact that a significant barrier to sustainable construction project financing is the perceived high cost of construction of such projects.

Not everyone easily gives in and embraces new technology, especially, if it demands changes in the conventional way of doing things. Since the introduction of the green building concept, developers and contractors have come to perceive that there is a risk of failure in the application of some new technologies or materials in the production of such buildings. This perception tends to put fear in investors who believe there is little 
chance of making profits on their investment should they invest in such projects (Bradshaw et al., 2005).

Research into the barriers that impede financing of the sustainable construction project has shown that one of the significant barriers not promoting the financing of such projects is the lack of a clear-cut policy or changing government policies for the financing of such projects (Soundarrajan and Vivek, 2016). In the United Kingdom, for instance, commitment to introducing policies and regulations by leadership might not be enough to push through the financing of sustainable buildings (Soundarrajan and Vivek, 2016). For private investors, because of such changing policies, they require confidence in the market before investing in such projects (Lehman et al., 2015). Some countries in Asia are now making efforts to ensure that there are suitable policies in place to enhance the financing of sustainable buildings through the introduction of sustainable financing guidelines and regulations (Volz, 2018).

\subsection{RESEARCH METHOD}

A quantitative approach in the form of a survey was adopted for this study. The extensive critical comparative review of literature in Section 2.3 was conducted and potential obstacles to green building project financing were identified. The literature reviewed provided a theoretical basis to underpin the study and laid the foundation for developing the survey questionnaire.

\subsection{Survey Design}

A two-part questionnaire was designed for this study. Several stakeholders and professionals are involved in investment issues related to green buildings. In this study, three important professionals were considered, namely, Building Contractors, 
Consultants, and Developers. Assessing the perception of each professional on the obstacles to green building project financing was done based on the judgment of those professionals.

Before the questionnaire was administered, a two-step piloting procedure was used to access its appropriateness for the intended purpose. In the first step, the questionnaire was reviewed by an expert in green building developments. In the second part of the piloting, interviews were conducted with 20 industry players of various backgrounds (general building contractors, consultants, and developers) who had experience in green buildings within the local context. They were also required to check the suitability of the questions asked and determine if to the best of their knowledge any obstacles have been omitted. They gave some encouraging feedback which resulted in the merging of some of the obstacles. Similar piloting had been used in other equally important green building-related studies (Chan et al., 2018; Zhao et al., 2016).

Following these feedbacks, the two-part questionnaire was finalized and sent out. In the first part, the demographic data of the respondents was obtained. In the second part, the views of the respondents were sought on the obstacles to green building project financing. Consequently, in this section, the professionals were required to rate the extent to which they perceive that the factors militated against the financing of green building projects. A five-point Likert scale $(1=$ not important, $2=$ less important, $3=$ quite important, $4=$ important and $5=$ very important) was used. The factors which the respondents were asked to assess were obtained from the extensive review of the literature as indicated in section 2.3. 


\subsection{Survey Administration}

The questionnaire was administered to the professionals (i.e. Building Contractors, Consultants, and Developers) in Ghana. Respondents within the Building Contractors category were selected from Class D1 building construction firms. Those within the Consultants were selected from the Institution of Engineering and Technology Ghana (IETG), Ghana Institute of Surveyors (GhIs), and the Ghana Institute of Architects. Respondents under the Developers category were selected from the Ghana Real Estates Developers Association (GREDA). In selecting the respondents, the emphasis was laid on the ability of that respondent to possess requisite knowledge and experience in sustainable construction.

Considering the difficulty in obtaining the exact number of D1 building contractors in Ghana, non-probability sampling approaches (i.e. purposive and snowball sampling approaches), was used. Based on this sampling approach, a total of 100 questionnaires were administered to the D1 building contractors and were further retrieved.

With regards to the consultants, the Ghana Institute of Surveyors is made up of members with different backgrounds, i.e. the valuation and estate surveying division, the land surveying division, and the quantity surveying division. With the information needed, those within the quantity surveying division were settled on and respondents were further sampled from them to partake in the survey. Per the records of the Ghana Institute of Surveyors, 387 quantity surveyors are working with various consultancy firms and are in good standing. Through the purposive and snowball sampling techniques, 100 respondents were identified to meet the set criteria and were subsequently invited to partake in the survey. Responses were received from all the 100 participants. 
As part of the consultancy group were those that were professional members of the Institution of Engineering and Technology Ghana. This professional body is made up of members with all engineering backgrounds. Hence, for the sake of this study, those members (i.e. construction, civil, and building) who fell within the boundaries set for the study were considered. Within the institution, 52 construction professionals, 15 civil engineering professionals, and 16 building engineering professionals are registered with various consultancy firms and are in good standing. Through the purposive and snowball sampling techniques, 50 of these members (i.e. construction, civil and building) in good standing were invited to take part in the survey, with responses received from all the participants. Within the Ghana Institute of Architects, 760 members were identified to be in good standing. Out of this number 150 was identified through the purposive and snowball sampling techniques to be working with various consultancy firms and with knowledge concerning sustainable building practices. All the 150 respondents were invited to partake in the survey, with responses received from all of them.

In the Developers group, the Ghana Real Estate Developers Association currently has full members in good standing to be 205 . Out of this number, 120 were identified to be associated with sustainable construction practices and were also invited for the survey. Data were retrieved from all the 120 firms that were contacted.

In all, out of the 520 questionnaires sent out (i.e. 100 to D1 building contractors, 300 to consultants, and 120 to developers), a response rate of $100 \%$ was achieved. This response rate was possible because of the personal identification of these professionals. 


\subsection{Data Analysis}

The questionnaire data were analysed with IBM SPSS v22. In addition to the descriptive (i.e. mean, standard deviation, and standard error) analysis conducted on the data, parametric tests in the form of inferential (i.e. One-Sample t-test and One-Way ANOVA) analysis were further conducted on the data. The parametric methods were used because the data from this study came from a normally distributed population (Johnson, 2009). When such assumptions are made, statistical tools such as t-test, ANOVA, and the likes are recommended. Where the requirements of the parametric tests are not met, the non-parametric test becomes suitable (Johnson, 2009).

Prior to these analyses, the Cronbach's Alpha Test was conducted to check the internal consistency of the scale used for the rating of the various barriers. A score of 0.70 and above indicates the scale being used for the rating is internally consistent (Bonett and Wright, 2014). The result of this test was 0.725 which means the Likert scale used to rate the obstacles were reliable. The obstacles were ranked by their mean based on the view of each respondent group.

The One-Sample T-Test was conducted to check the various means of the obstacles against a mean test value of 3.50. In this case, the null hypothesis $\left(\mathrm{H}_{0}\right)$ was defined to mean that the mean score was not statistically significant and the alternative hypothesis $\left(\mathrm{H}_{1}\right)$ was defined to mean that the mean score was statistically significant. The onesample T-Test was conducted at a $95 \%$ confidence level with a $p$-value of 0.05 . The null hypothesis was rejected where $p<0.05$ at a $95 \%$ confidence level while the alternative hypothesis $\left(\mathrm{H}_{1}\right)$ held where $p>0.05$ at a $95 \%$ confidence level. Also, the One-Way ANOVA was further used to compare the means of the three different participant 
groups to determine if there was any statistically significant difference among the means of the groups.

\subsection{RESULTS AND DISCUSSION}

The results of the study are presented and discussed under two subheadings to include the following: respondent demographic background; and perceptions of professionals on the obstacles to green building project financing.

\subsection{Respondent demographic background}

The respondents were obtained from building construction companies, consultancy firms, and developers, and their background information is presented as follows. The respondents occupied various positions or roles in their respective firms ranging from Quantity Surveyors (19.23\%), Architects (28.85\%), Building Construction Engineers (7.31\%), Civil Engineers (2.31\%), Project Managers (19.23\%), and Real Estate Developers (23.07\%). Most of the respondents held Master's (67.69\%) and bachelor's Degrees (25.96\%) respectively, and over half of them had over 10 years of working experience. This information shows that the respondents were in the position to adequately give meaningful information needed for the study.

\subsection{Professionals' perceptions on the obstacles to green building project financing}

For the various obstacles examined, the respondents rated the extent to which they can hinder the financing of green building projects. Table 1 shows that all the obstacles had mean scores above the test value of 3.5, suggesting that all the ten obstacles posed as hindrances to the financing of green building projects. To verify the reliability of the five-point scale by measuring the internal consistency among the various factors, Kendall's Coefficient analysis was used. According to Chan et al. (2009), overall 
agreement amongst sets of rankings can be ascertained by using Kendall's coefficient of concordance. For Kendall's W, 'no agreement' and 'complete agreement' are represented by the values 0 and +1 respectively from a range 0 to +1 . The Kendall's W values for this study were 0.164 which illustrates a degree of less agreement amongst the sets of rankings. Furthermore, all the obstacles had $p$-values less than 0.05 for the one-tailed test. This gives a strong indication of the statistical significance of the various obstacles that hinder the financing of green building projects.

Based on the ranking which corresponds to the perceptions of the respondents, the five key obstacles to the green building project financing in Ghana are split incentives [Mean score $(M S)$ 4.55, Standard deviation $(S D)=0.709]$, risk-related barriers $[M S=$ 4.52, $S D=0.639]$, capital expenditure $[M S=4.41, S D=0.601]$, lack of incentives [MS $=4.35, S D=0.655]$, and initial capital cost $[M S=4.33, S D=0.739]$. The other equally important obstacles were identified as changing government policies [MS = 4.31, $S D=0.738]$, inadequate financing schemes $[M S=4.30, S D=0.730]$, lack of credible information databases $[M S=3.77, S D=0.798]$, lack of knowledge about green building benefits [MS =3.74, SD =0.798], and new technology [MS $=3.63, S D$ $=0.912]$.

[Insert Table 1 near here]

While the mean score ranking only showed the professionals' views of the extent to which the factors examined posed as obstacles to green building project financing, the One-Way ANOVA was necessary to determine whether there are any statistically significant differences in the views of the professionals regarding any of the obstacles. 
The results from the ANOVA are presented in Table 2. From the One-Way ANOVA test, the combined sample revealed that there are differences in the views of the various professionals (i.e. contractors, consultants, and developers) regarding four out of the 10 obstacles examined. The four obstacles which showed the differences are lack of credible information database, risk-related barriers, lack of knowledge about green building benefits, and new technology.

[Table 2 near here]

Following this revelation, a Tukey post hoc comparison (see Table 3) was carried out to determine the differences in the views of the professionals regarding the four identified obstacles. According to De Vaus (2002), the post hoc is normally used together with ANOVA to show the pairs of groups that show statistically significant mean differences. Skibniewski and Ghosh (2009) further indicated that for the Tukey's test, a pairwise comparison with means that significantly differ from each other at 0.05 significance level is detected. The differences in the mean scores of the various groups from the post hoc and the mean differences are shown in Table 3. For the pairs of the groups that showed statistically significant mean differences at a significance level of 0.05 , they are denoted by the superscript " $*$ ". The researchers found it to be amazing as to why for professionals within the same fraternity, i.e. The Built Environment, such differences could arise in their perceptions regarding these four obstacles. The discussions were centred around what could have given rise to the differences in their views regarding the four obstacles. The discussion is as follows:

[Table 3 near here] 


\subsubsection{Lack of credible information database}

From Table 3, it is seen that the mean score of the views of the contractors on the obstacle lack of credible information database is significantly higher than that of the consultants [Mean difference, $\mathrm{MD},=0.377, p=0.000<0.05]$. The comparison of the mean scores of the contractors with developers [MD $= \pm 0.197, p=0.155>0.05]$, and consultants with developers $[\mathrm{MD}= \pm 0.180, p=0.087>0.05]$ yielded no significant differences for this obstacle.

In the development of green buildings, there is a combination of multiple economic sectors from an industrial chain for planning, architecture design, material manufacturing, construction to operation management, and demolition (Deng et al., 2018). This notwithstanding, moving towards the green building paradigm requires a shift from current architecture, construction technologies, and practices (Berry et al., 2013). This implies that for any company to get involved in this paradigm shift, a credible information database should be available where such details have been catalogued. Without credible green building information databases, the green building market may suffer.

From this finding, it is evident that the general building contractor perceived a lack of credible information database to be more critical than the consultants and developers because they find it difficult to obtain information and data related to green buildings within the current Ghanaian construction markets. With this information lacking, it will be difficult for the construction industries to fully invest their money in such projects. General building contractors need a credible information database on the pre- 
construction, construction, and the project completion phases of similar green building projects to assist them to ensure job quality, monitor the success of current projects, and to have complete and consistent documentation of such sustainable projects for their future references. According to Chan et al. (2018), currently, in Ghana, these credible databases are missing because of the inadequate green building suppliers.

\subsubsection{Risk-related barriers/obstacles}

Table 3 again shows that for the obstacle risk-related barriers, the mean scores of the views of the contractors are significantly higher than that of the consultants $[\mathrm{MD}=$ $0.173, p=0.049<0.05]$ and the developers $[\mathrm{MD}=0.220, p=0.029<0.05]$, an indication of the differences in the views of the professionals regarding this obstacle. However, the comparisons of the consultants with the developers $[\mathrm{MD}=0.047, \mathrm{p}=$ $0.775>0.05]$ showed no significant difference for this obstacle.

Most of the time, different professionals have different interests in green building projects. These interests depict the kind of risks which the professionals are exposed to. From the finding, the difference in the views of the contractors and consultants can be likened to their different interests in financing green building projects. For instance, in a typical construction procurement process, the contractor bids on a project and is responsible for completing the construction for the agreed-upon price. Since the contractor is liable for anything that might go wrong on the job, they focus on minimizing various risks whiles completing the project as quickly and inexpensively as possible to maximize their profit. 
For general building contractors, studies have shown that regulatory, financial, performance, (Sub) consultants and subcontractors, and standard of care or legal risks the five risk categories which hinder their investment in green building projects (Modugno, 2009). Failure of the contractors in dealing with these risks come with a lot of penalties. On the other hand, the consultants (e.g. quantity surveyors) have their responsibilities defined based on the method used for the building procurement. As a result of this, their attention is basically on the risks associated with the roles they will perform within the green building project procurement route.

\subsubsection{Lack of knowledge about green building benefits}

For this obstacle, Table 3 shows that the mean score of the views of the consultants is significantly higher than that of the contractors $[\mathrm{MD}=0.437, p=0.000<0.05]$. Also, the mean score of the views of the developers is significantly higher than that of the contractors $[\mathrm{MD}=0.367, \mathrm{p}=0.002<0.05]$. However, there is no significant difference in the mean scores of the consultants and developers [MD $=0.070, \mathrm{p}=0.686>0.05]$.

It is not surprising that there were differences in the views of the professionals regarding this obstacle. Since the finding from this study has established that there is inadequate credible data information on green building projects in Ghana how can various professionals gain knowledge on the benefits associated with such buildings? This finding is therefore concurrent with the first obstacle discussed, i.e. the lack of credible information database on green buildings.

Many professionals within the developers, consulting, and contracting firms in Ghana have not been able to keep pace with the various green building developments because 
of the lack of knowledge which results from inadequate credible data on such projects. Based on this, these professionals must begin to educate themselves about the various benefits associated with investing in green buildings. This is possible if the industry players adhere to the advice provided by Chan et al. (2018) concerning the need for professionals to come to a consensus on developing a comprehensive national green building database to provide professionals like the building contractors with accurate and updated information about green building technologies, and that of Shi et al. (2013) concerning how the industry associations could play a significant role through the sharing of relevant green building project information and its associated benefits with contractors to boost their morale in investing in such projects.

\subsubsection{New technology}

Finally, Table 3 shows that the mean score of the views of the contractors on the obstacle new technology is significantly higher than that of the consultants $[\mathrm{MD}=$ $0.377, p=0.000<0.05]$. The contemporary green building is relatively young in Ghana, and it comes with innovative new approaches and technologies to improve the performance of buildings. The result shows that for the obstacle new technology, there exist significant differences in the views of the contractors and consultants. The differences in the views of these professionals stem from the type of technology that each will need to carry out their part of the building delivery process. In most instances, the consultants are much concerned about the new technologies they are required to incorporate within the briefing stage, sketch design stage, and the working drawing stage. Within this stage, they perceive additional tasks to be associated with the introduction of the new technologies. 
General contractors, on the other hand, have a lot to concern themselves about because they will need to put in place creative strategies to keep up with the new trends while still staying efficient, effective, and competitive. They need to be involved early in all the green building delivery processes. When this happens, they can put themselves in the position to embrace and give input into any new technologies that are proposed. These tedious tasks which involve the application of new tools and techniques make it sometimes difficult for these professionals to invest in green building projects.

\subsection{CONCLUSION}

This study was conducted to examine the perception of professionals, i.e. general building contractors, consultants, and developers regarding obstacles to green building project financing in Ghana. Following an extensive critical comparative review of literature that led to the identification of ten potential obstacles, a cross-sectional survey was conducted among some key industry professionals. The findings from the study suggest that all the ten obstacles were identified by the professionals to hinder the financing of green building projects. However, five out of these ten, i.e. split incentives, risk related barriers, capital expenditure, lack of incentives, and initial capital cost were identified as the key obstacles.

Following further analysis based on inferential statistics (i.e. One-Way ANOVA), it was revealed that there were differences in the views of the various professionals (i.e. contractors, consultants, and developers) regarding four out of the 10 obstacles examined, with those obstacles identified to be lack of credible information database, risk-related barriers, lack of knowledge about green building benefits, and new technology. Analysing these four obstacles further, it was found that for those obstacles 
where there were differences, such differences resulted from the fact that the different professionals have different interests in green building projects, and those interests depicted the kind of risk which they were exposed to.

The findings hold significant practical implications since identifying that, it is the interests of the various professionals that trigger the differences in their views regarding some of the obstacles provides the bases to put in place measures to control such interests and to promote their interests to invest in green building projects. That is, the identification of these obstacles should not in any way obscure the overall direction of green building project financing. From the many information available, it is evident that green buildings are now emerging as the new standard in the construction industry, and because it is driven by government regulations, the demand from consumers and the increasing awareness of its economic, social and environmental benefits, the demand for green buildings may only become more prominent with time. Hence, it is only right for industry professionals to put in place appropriate measures to control their differences regarding these obstacles and to find appropriate measures to control these obstacles to avoid exposing themselves to the risks which they may encounter due to their unpreparedness for the green building transformation.

Considering the unique nature of the construction industry, the differences in the views of the professionals regarding the obstacles may manifest differently in different national contexts, hence, there is the need for studies of this nature to be carried out in other developing country contexts to understand what pertains in those countries. A limitation of this study is that the views of some other key stakeholders such as the government, financial institutions, consumers, and the likes were not sought after. 
Future studies can be conducted in this respect to provide additional empirical realities that can broaden the understanding of the views of other stakeholders on the obstacles to green building project financing and how to alleviate such obstacles.

\section{References}

Agyekum, K., Adinyira, E. and Ampratwum, G. 2020. Factors driving the adoption of green certification of buildings in Ghana. Smart and Sustainable Built Environment. Vol. ahead-of-print No. ahead-of-print. Doi: 10.1108/SASBE-02-20190017.

Agyekum, K., Adinyira, E., Baiden, B., Amprtwum, G. and Duah, D. 2019. Barriers to the adoption of green certification of buildings: A thematic analysis of verbatim comments from Built Environment Professionals. Journal of Engineering, Design and Technology. doi: 101108/JEDT-01-2019-0028: 1-22.

Ampratwum, G., Agyekum, K., Adinyira, E. and Duah, D. 2019. A framework for the implementation of green certification of buildings in Ghana, International Journal of Construction Management, DOI: 10.1080/15623599.2019.1613207.

Azizi, N.S.M. 2010. Risks associated with the implementation of green buildings. In Procs. $4^{\text {th }}$ International Conference on Sustainability Engineering and Science, Faculty of Engineering, The University of Auckland, Auckland, New Zealand.

BCA. Singapore: Leading the Way for Green Buildings in the Tropics. 2014. Available online: https://www.bca.gov.sg/greenmark/others/sg_green_buildings_tropics.pdf (accessed on 21 March 2019).

Berry, S., Davidson, K. and Saman, W. 2013. The impact of Niche Green Developments in transforming the building Sector: The Case Study of Lochiel Park." Energy Policy 62: 646-655.

Bird, S. and Hernandez, D. 2012. Policy options for the split incentive: Increasing energy efficiency for low-income renters, Energy Policy, Vol. 48, pp. 506-514.

Chan, A.P.C., Darko, A., Olanipekun, A.O. and Ameyaw, E.E. 2018. Critical barriers to green building technologies in developing countries: The case of Ghana. Journal of Cleaner Production. 172 (2018):1067-1079.

Chan, A.P., Lam, P.T., Chan, D.W., Cheung, E. and Ke, Y. 2009. Drivers for adopting public private partnerships-Empirical comparison between china and Hong Kong special administrative region. Journal of Construction Engineering and Management. $135: 1115-1124$.

Clark, R. Reed, J. Sunderland, T. 2018. Bridging funding gaps for climate and sustainable development: Pitfalls, progress and potential of private finance, Land Use Policy, Vol. 71, pp. 335-346 
Cui, Y., Geobey, S., Weber, O. and Lin, H. 2018. The impact of green lending on credit risk in China. Sustainability. 10(6):2008.

Deng, W., Yang, T., Tang, L. and Tang, Y-T. 2018. Barriers and policy recommendations for developing green buildings from local government perspective: a case study of Ningbo, China. Intelligent Buildings International. 10(2):61-77.

Durdyev, S., Ismail, S., Ihtiyar, A., Abu Bakar, N.F.S. and Darko, A. 2018. A partial least squares structural equation modeling (PLS-SEM) of barriers to sustainable construction in Malaysia. Journal of Cleaner Production, Vol. 204, pp. 564-572

Durmus-Pedini, A. and Ashuri, B. 2010. An overview of the benefits and risk factors of going green in existing buildings. International Journal of Facility Management, Vol. 1 No.1, pp. 1-15.

G20 Green Finance Study Group. 2016. G20 Green Finance Synthesis Report.

Gou, Z., Lau, S.S.Y. and Prassad, D. 2013. Market readiness and policy implications for green buildings: Case study from Hong Kong, Journal of Green Buildings, Vol. 8 No.2, pp. 162-173.

Green Climate Fund, GCF. 2017. Scaling-up investments in low-carbon public buildings. Available at: https://www.greenclimate.fund/project/fp051, accessed 15 December 2019.

Höhne / Khosla / Fekete / Gilbert. 2012. Mapping of Green Finance Delivered by IDFC Members in 2011, Ecofys.

Hwang, B.-G., Shan, M. and Supa'at, N.N.B. 2017. Green commercial building projects in Singapore: critical risk factors and mitigation measures. Sustainable Cities and Society, Vol. 30, pp. 237-247.

International Finance Corporation, IFC. 2017. Green Buildings Market Intelligence: Ghana Country Profile”, Available at: https://www.ifc.org, Accessed 20 Febuary 2019

Johnson, R. 2009. Choosing between parametric and non-parametric tests. Journal of Undergraduate Research at Minnesota State University, Mankato: Vol. 9, No. 6, pp. 115.

Kriss, J. What is Green Building? 2014. Available online: https://www.usgbc.org/articles/what-green-building (accessed on 21 March 2019).

Lee, S., Lee, B., Kim, J. and Kim, J. 2013. A financing model to solve financial barriers for implementing green building projects. The Scientific World Journal. 2013 (3):240394. 
Mao, X.; Lu, H.; Li, Q. A Comparison Study of Mainstream Sustainable/Green Building Rating Tools in the World. In Proceedings of the 2009 International Conference on Management and Service Science, Wuhan, China, 20-22 September 2009; pp. 1-5.

Modugno, A. 2009. Green building: Assessing the risk. Available at: https://cdn.ymaws.com/acrel.site-ym.com/resource/collection/D1CFEE37-A66B-47129DFC-6687A87B1FD9/Maloney_ACREL_Exhibit_3.pdf, accessed 3 June 2020

MOHURD. Evaluation Standard for Green Building (GB/T 50378-2014); MOHURD: Beijing, China, 2015; p.2.

Nduka, D.O and Sotumbo, A.S. 2014. Stakeholders perceptions on the awareness of green building rating systems and accruable benefits in construction projects in Nigeria, Journal of Sustainable Development in Africa, Vol. 16 No. 7, pp. 118-130.

Oluwunmi, A.O., Oladayo, O.P., Role, B.A. and Afolabi, T.O. 2019. Benefits and barriers to the implementation of green building standards in universities: What are students' views? Materials Science and Engineering, 640(2019), pp. 1-12. Doi: 10.1088/1757-899X/640/1/012031.

Qin, X., Mo, Y. and Jing, L. 2016. Risk perceptions of the life-cycle of green buildings in China. Journal of Cleaner Production, Vol. 126, pp. 148-158.

Salman, M.T.F., Sayegh M.W and Ayoubi, M.A. 2016. Green Bonds. Available at: http://www.cedro-undp.org, accessed 10 December 2019.

Shan, M., Hwang, B.G. and Zhu, L. 2017. A global review of sustainable construction project financing: policies, practices, and research efforts", Sustainability, 9(12):2347.

Shi, Y. and Liu, X. 2019. Research on the literature of green building based on the web of science: A scientometric analysis in CiteSpace (2002-2018)". Sustainability. 11(2019):1-22.

Simpeh, E. and Smallwood, J. 2015. Factors influencing the growth of green building in the South African construction industry. In Procs. of Smart and Sustainable Built Environment Conference, Pretoria, 9-11 December.

Soundarrajan, P. and Vivek, N. 2016. Green finance for sustainable green economic growth in India”, Agricultural Economics, 62(1):35-44.

Sourani, A. and Sohail, M. 2011. Barriers to addressing sustainable construction in public procurement strategies, Engineering Sustainability, Vol. 164 No. 4, pp. 229-237.

Tam, V.W.Y., Le, K.N., Tran, C.N.N. and Illankoon, I.M.C.S. 2019. A review on nternational ecological legislation on energy consumption: greenhouse gas emission management, International Journal of Construction Management, DOI: 10.1080/15623599.2019.1576259. 
United Nations Department of Economics and Social Affairs, UNDESA. 2017. The world population prospects: The 2017 revision. Available at: https://www.un.org/development/desa/en/news/population/world-population-prospects2017.html, accessed 27 May 2020.

US Environmental Protection Agency Definition of Green Building, 2015. Available: http://archive.epa.gov/greenbuilding/web/html/about.html, accessed 26/01/2019.

United Nations Environmental Programme, UNEP. 2010. Green buildings and the finance sector: An overview of financial institution involvement in green buildings in North America. A report commissioned by the North American the North American Task Force, UNEP Finance initiative.

Unite States Environmental Protection Agency, USEPA. 2009. Buildings and their Impact on the Environment: A Statistical Summary. 2009. Available at: https://archive.epa.gov/greenbuilding/web/pdf/gbstats.pdf (accessed on 26 March 2020).

Volz, U. 2018. Fostering green finance for sustainable development in Asia. ADBI working paper, No. 814, Asian Development Bank Institute, Tokyo.

Walter, K., Cochu, A., Georgiev, I., Eisinger, F. and Hogg, D. 2017. Defining 'green' in the context of green finance. Available at: http://www.europa.eu, (accessed 29 May 2020).

Weber, O., Diaz, M. and Schwegler, R. 2014. Corportae social responsibility of the financial sector-strengths, weaknesses and impacts on sustainable development, Sustainable Development, Vol. 22 No. 5, pp. 321-335.

World Green Building Council. World Green Building Trends 2018. 2018. Available online: $\quad$ https://www.worldgbc.org/news-media/world-green-building-trends-2018smartmarket-report-publication (accessed on 20 March 2019).

Yang, R.J., Zou, P.X.W. and Wang, J. 2016. Modelling stakeholder-associated risk networks in green building projects. International Journal of Project Management, Vol. 34 No. 1, pp. 66-81.

Zadek and Flynn. 2013. South-Originating Green Finance: Exploring the Potential, The Geneva International Finance Dialogues, UNEP FI, SDC, and iisd.

Zhao, X., Hwang, B-G. and Lee, H.N. 2016. Identifying critical leadership styles of project managers for green building projects. International Journal of Construction Management, Vol. 16 No. 2, pp. 150-160.

Zhan, C. and de Jong, M. 2018. Financing eco cities and low carbon cities: The case of Shenzhen International Low Carbon City. Journal of Cleaner Production, pp. 180, Available at: https://116-125. doi: 10.1016/j.jclepro.2018.01.097 
Zhao, X., Hwang, B-G. and Gao, Y. 2016. A fuzzy synthetic evaluation approach for risk assessment : a case of Singapore's green projects. Journal of Cleaner Production. Vol. 115, pp. 203-213.

Zhang, L.; Wu, J.; Liu, H. 2018. Turning green into gold: A review on the economics of green buildings. J. Clean. Prod. 172:2234-2245.

Zhang, Y., Wang, H., Gao, W., Wang, F., Zhou, N., Kammen, D.M. and Ying, X. 2019. A survey of the status and challenges of green building development in various countries. Sustainability. 11:1-29.

Zuo, J. and Zhao, Z. 2014. Green building research-current status and future Agenda: A review. Renewable and Sustainable Energy Reviews. 30:271-281. 
Table 1. Summary analysis of obstacles to green building project financing

\begin{tabular}{l|l|l|l|l|l|l}
\hline \hline \multirow{2}{*}{ No } & \multirow{2}{*}{ Obstacles } & & & Test Value 3.5 & & \\
\cline { 3 - 7 } & & Mean & $\begin{array}{l}\text { Standard } \\
\text { Deviation }\end{array}$ & Sig One - Tailed & Rank & $\begin{array}{l}\text { Statically } \\
\text { Significant }\end{array}$ \\
\hline \hline & $\begin{array}{l}\text { Lack of credible information } \\
\text { database }\end{array}$ & 3.77 & .798 & 0.000 & 8 & Yes \\
\hline 2 & Risk related barriers & 4.52 & .639 & 0.000 & 2 & Yes \\
\hline 3 & $\begin{array}{l}\text { Lack of knowledge about } \\
\text { green building benefits }\end{array}$ & 3.74 & .798 & 0.000 & 9 & Yes \\
\hline 4 & $\begin{array}{l}\text { Inadequate financing } \\
\text { schemes }\end{array}$ & 4.30 & .730 & 0.000 & 7 & Yes \\
\hline 5 & Capital expenditure & 4.41 & .601 & 0.000 & 3 & Yes \\
\hline 6 & Split incentives & 4.55 & .709 & 0.000 & 1 & Yes \\
\hline 7 & Lack of incentives & 4.35 & .655 & 0.000 & 4 & Yes \\
\hline 8 & New technology & 3.63 & .912 & 0.002 & 10 & Yes \\
\hline 9 & $\begin{array}{l}\text { Changing government } \\
\text { policies }\end{array}$ & 4.31 & .738 & 0.000 & 6 & Yes \\
\hline 10 & Initial capital cost & 4.33 & .739 & 0.000 & 5 & Yes \\
\hline \hline & $\begin{array}{l}\text { Kendall's W } \\
\text { Chi Square }\end{array}$ & & & & & \\
\hline \hline
\end{tabular}


Table 2. One-Way ANOVA test to determine the significant differences in means between groups

\begin{tabular}{|c|c|c|c|c|c|c|}
\hline Obstacles & & $\begin{array}{l}\text { Sum of } \\
\text { Squares } \\
\end{array}$ & $\mathrm{df}$ & $\begin{array}{l}\text { Mean } \\
\text { Square }\end{array}$ & $\bar{F}$ & Sig. \\
\hline \multirow{3}{*}{$\begin{array}{l}\text { Lack of credible information } \\
\text { database }\end{array}$} & Between Groups & \multirow{3}{*}{$\begin{array}{l}11.321 \\
319.523 \\
330.844 \\
\end{array}$} & \multirow{3}{*}{$\begin{array}{l}2 \\
517 \\
519\end{array}$} & \multirow{3}{*}{$\begin{array}{l}5.660 \\
.618\end{array}$} & \multirow[t]{3}{*}{9.159} & \multirow[t]{3}{*}{.000} \\
\hline & Within Groups & & & & & \\
\hline & Total & & & & & \\
\hline \multirow{3}{*}{ Risk related barriers } & Between Groups & \multirow{3}{*}{$\begin{array}{l}3.001 \\
208.807 \\
211.808\end{array}$} & 2 & \multirow{3}{*}{$\begin{array}{l}1.501 \\
.404\end{array}$} & \multirow[t]{3}{*}{3.715} & \multirow[t]{3}{*}{.025} \\
\hline & Within Groups & & 517 & & & \\
\hline & Total & & 519 & & & \\
\hline \multirow{3}{*}{$\begin{array}{l}\text { Lack of knowledge about green } \\
\text { building benefits }\end{array}$} & Between Groups & 14.442 & 2 & 7.221 & 11.797 & .000 \\
\hline & Within Groups & 316.463 & 517 & \multirow[t]{2}{*}{.612} & & \\
\hline & Total & 330.906 & 519 & & & \\
\hline \multirow{3}{*}{ Inadequate financing schemes } & Between Groups & \multirow{3}{*}{$\begin{array}{l}.061 \\
276.737 \\
276.798\end{array}$} & 2 & \multirow{3}{*}{$\begin{array}{l}.031 \\
.535\end{array}$} & \multirow[t]{3}{*}{.057} & \multirow[t]{3}{*}{.944} \\
\hline & Within Groups & & 517 & & & \\
\hline & Total & & 519 & & & \\
\hline \multirow{3}{*}{ Capital expenditure } & Between Groups & \multirow{3}{*}{$\begin{array}{l}.095 \\
187.657 \\
187.752\end{array}$} & 2 & \multirow{3}{*}{$\begin{array}{l}.048 \\
.363\end{array}$} & \multirow[t]{3}{*}{.131} & \multirow[t]{3}{*}{.877} \\
\hline & Within Groups & & 517 & & & \\
\hline & Total & & 519 & & & \\
\hline \multirow{3}{*}{ Split incentives } & Between Groups & \multirow{3}{*}{$\begin{array}{l}.766 \\
259.832 \\
260.598\end{array}$} & 2 & \multirow{3}{*}{$\begin{array}{l}.383 \\
.503\end{array}$} & \multirow[t]{3}{*}{.762} & \multirow[t]{3}{*}{.467} \\
\hline & Within Groups & & 517 & & & \\
\hline & Total & & 519 & & & \\
\hline \multirow{3}{*}{ Lack of incentives } & Between Groups & \multirow{3}{*}{$\begin{array}{l}.044 \\
222.848 \\
222.892\end{array}$} & 2 & .022 & .051 & .950 \\
\hline & Within Groups & & 517 & .431 & & \\
\hline & Total & & 519 & & & \\
\hline & Between Groups & 11.321 & 2 & 5.660 & 9.159 & .000 \\
\hline New technology & Within Groups & 319.523 & 517 & .618 & & \\
\hline & Total & 330.844 & 519 & & & \\
\hline & Between Groups & .726 & 2 & .363 & .666 & .514 \\
\hline Changing government policies & Within Groups & 281.657 & 517 & .545 & & \\
\hline & Total & 282.383 & 519 & & & \\
\hline & Between Groups & 2.506 & 2 & 1.253 & 2.306 & .101 \\
\hline Initial capital cost & Within Groups & 280.938 & 517 & .543 & & \\
\hline & Total & 283.444 & 519 & & & \\
\hline
\end{tabular}


Table 3. Tukey post hoc test multiple comparison table for professionals' views

\begin{tabular}{|c|c|c|c|c|c|c|c|}
\hline \multirow[t]{2}{*}{ Dependent Variable } & \multirow[t]{2}{*}{$\begin{array}{l}\text { Professional } \\
\text { (I) }\end{array}$} & \multirow[t]{2}{*}{$\begin{array}{l}\text { Professional } \\
\text { (J) }\end{array}$} & \multirow{2}{*}{$\begin{array}{l}\text { Mean } \\
\text { Difference } \\
\text { (I-J) }\end{array}$} & \multirow[t]{2}{*}{$\begin{array}{l}\text { Std. } \\
\text { Error }\end{array}$} & \multirow[t]{2}{*}{ Sig. } & \multicolumn{2}{|c|}{$\begin{array}{l}\text { 95\% Confidence } \\
\text { Interval }\end{array}$} \\
\hline & & & & & & $\begin{array}{l}\text { Lower } \\
\text { Bound }\end{array}$ & $\begin{array}{l}\text { Upper } \\
\text { Bound }\end{array}$ \\
\hline \multirow{6}{*}{$\begin{array}{l}\text { Lack of credible } \\
\text { information } \\
\text { database }\end{array}$} & \multirow[t]{2}{*}{ Contractors } & Consultants & $.377^{*}$ & .091 & .000 & .16 & 2.59 \\
\hline & & Developers & .197 & .106 & .155 & -.05 & .45 \\
\hline & \multirow[t]{2}{*}{ Consultants } & Contractors & $-.377^{*}$ & .091 & .000 & -.59 & -.16 \\
\hline & & Developers & -.180 & .085 & .087 & -.38 & .02 \\
\hline & \multirow[t]{2}{*}{ Developers } & Contractors & -.197 & .106 & .155 & -.45 & .05 \\
\hline & & Consultants & .180 & .085 & .087 & -.02 & .38 \\
\hline \multirow{6}{*}{$\begin{array}{l}\text { Risk related } \\
\text { barriers }\end{array}$} & \multirow[t]{2}{*}{ Contractors } & Consultants & $.173^{*}$ & .073 & .049 & .00 & .35 \\
\hline & & Developers & $.220^{*}$ & .086 & .029 & .02 & .42 \\
\hline & \multirow[t]{2}{*}{ Consultants } & Contractors & $-.173^{*}$ & .073 & .049 & -.35 & .00 \\
\hline & & Developers & .047 & .069 & .775 & -.11 & .21 \\
\hline & \multirow[t]{2}{*}{ Developers } & Contractors & $-.220^{*}$ & .086 & .029 & -.42 & -.02 \\
\hline & & Consultants & -.047 & .069 & .775 & -.21 & .11 \\
\hline \multirow{6}{*}{$\begin{array}{l}\text { Lack of } \\
\text { knowledge about } \\
\text { green building } \\
\text { benefits }\end{array}$} & \multirow[t]{2}{*}{ Contractors } & Consultants & $-.437^{*}$ & .090 & .000 & -.65 & -.22 \\
\hline & & Developers & $-.367^{*}$ & .106 & .002 & -.62 & -.12 \\
\hline & \multirow{2}{*}{ Consultants } & Contractors & $.437^{*}$ & .090 & .000 & .22 & .65 \\
\hline & & Developers & .070 & .085 & .686 & -.13 & .27 \\
\hline & \multirow[t]{2}{*}{ Developers } & Contractors & $.367^{*}$ & .106 & .002 & .12 & .62 \\
\hline & & Consultants & -.070 & .085 & .686 & -.27 & .13 \\
\hline \multirow{6}{*}{ New technology } & \multirow[t]{2}{*}{ Contractors } & Consultants & $.377^{*}$ & .091 & .000 & .16 & .59 \\
\hline & & Developers & .197 & .106 & .155 & -.05 & .45 \\
\hline & \multirow[t]{2}{*}{ Consultants } & Contractors & $-.377^{*}$ & .091 & .000 & -.59 & -.16 \\
\hline & & Developers & -.180 & .085 & .087 & -.38 & .02 \\
\hline & \multirow[t]{2}{*}{ Developers } & Contractors & -.197 & .106 & .155 & -.45 & .05 \\
\hline & & Consultants & .180 & .085 & .087 & -.02 & .38 \\
\hline
\end{tabular}

